\title{
原著論文
}

\section{硬質レジン歯への光重合型コンポジットレジン 添加時における効果的な表面処理について}

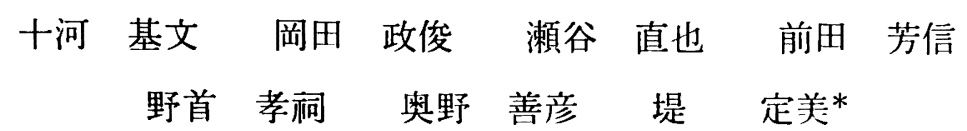

\author{
Effective Treatment Method for Repairing Damaged Surfaces of \\ Hard Type Acrylic Denture Teeth with Light Curing Composite Resin
}

\author{
Motofumi Sogo, Masatoshi Okada, Naoya Seya, Yoshinobu Maeda, \\ Takashi Nokubi, Yoshihiko Okuno and Sadami Tsutsumi*
}

\begin{abstract}
Damaged or worn down acrylic denture teeth are often repaired using a self-curing acrylic resin or a composite resin. Recently hard type acrylic (HA) artificial teeth have been used clinically because of higher wear resistance.

In some cases, however reconstruction of the $\mathrm{HA}$ denture teeth are still needed. In this study, we tried to find an effective treatment method for repairing damaged surfaces of HA denture teeth with a light curing composite resin which has good wear resistance and better chance of manipulation. The shear bond strength of a light curing composite resin to HA denture teeth, was evaluated after applying to bonding surface, four different agent and their combinations. They were an etching (E), an organic solution (Rebase Aid; RA), a silanecoupling agent (Porcelain Liner $\mathrm{M} ; \mathrm{PL}$ ), and a bonding agent (B), combinations were $\mathrm{E}+\mathrm{B}$, $\mathrm{E}+\mathrm{RA}+\mathrm{B}, \mathrm{E}+\mathrm{PL}+\mathrm{B}$ and $\mathrm{E}+\mathrm{RA}+\mathrm{PL}+\mathrm{B}$.

As the result, maximum strength was obtained $\mathrm{E}+\mathrm{RA}+\mathrm{PL}+\mathrm{B}$, about $130 \mathrm{kgf} / \mathrm{cm}^{2}$. According to our results, clinically damaged or worn down HA denture teeth should be repaired with a light curing composite resin after occlusal surface treatment with an etching, an organic solution (RA), a silanecoupling (PL) and a bonding agent.
\end{abstract}

Key words : hard type acrylic denture tooth, adhesive agent, bonding strength

大阪大学齒学部歯科補緅学第二諥座 (主任 : 奥野善彦教授)

* 京都大学生体医療工学研究センター医用システム工学領域

The Second Department of Prosthetic Dentistry, Osaka

University Faculty of Dentistry (Chief : Prof. Yoshihiko
Okuno)

* Research Center for Biomedical Engineering, Kyoto University 平成 2 年 5 月 31 日受付 


\section{I. 緒言}

アクリリックレジン歯は陶歯に比べて床用レジンとの 結合力が強いため脱落しにくく, 破折も生じにくい, ま た咬合調整（削合，研磨）が簡便であるため，日常臨床 で広く使用される.

しかしながら，短所として耐摩耗性において著しく劣 るため, 咀嚼能率の低下, 咬合の不調和, ひいては支持 組織，支台歯への咬合力の伝達・分散の変化による障害 または顎位の変位などを起こしやすい.

近年この短所を改善する目的で, 従来のアクリリック レジン歯と比較して耐摩耗性, 強度に優れた硬質レジン 歯が開発された。しかしアクリリックレジン歯に比べて 量的には影著に少ないものの, 長期間使用時には摩耗が 生じる ${ }^{1)}$ と思われるので, その際の対応が必要である. また，硬質レジン歯についてはこれまで破折 ${ }^{2)}$, 床用レ ジンとの結合力 ${ }^{3 \sim 5)}$ に関する研究はされてきているが, 摩耗時の対応における添加調整に関する研究6)はみられ ない.

そこで今回, 著者らは硬質レジン歯への添加調整の場 合, 現在臨床上頻繁に使用され，耐摩耗性に優れてお り，操作が容易で口腔内においては生体に調和した咬合 面再構成が可能である可視光線重合型コンポジットレジ ンを利用し，その効果的な人工歯の表面処理条件を検討 する目的で両者の接着強さを指標として以下の実験を行 った.

\section{II. 実験材料}

実験に使用した硬質レジン人工歯として ENDURA POSTERIO (松風社製，以下 Endura と略す）を，また 可視光線重合型コンポジットレジンとしてセミハイブリ ッド型7) LITE-FIL P (松風社製) を使用した. なおエッ チング剂とボンディング剤は，LITE-FIL P 附属の LITE-FIL BOND（松風社製：以下 E 剂, B 剂と略す） を使用した。

人工歯表面処理剤として, 塩素系有機溶剂 REBASE AID (徳山曹達社製，以下 RA と略す）と，4-META 含 有 MMA 系シランカップリング剂 Porcelain Liner M （Sun-Medical 社製，以下 PL と略す）を使用した.

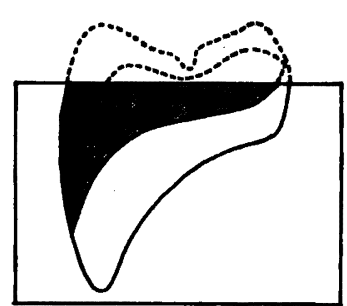

a

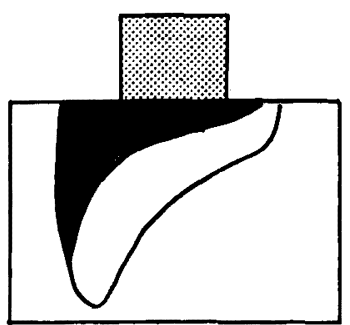

b
口: 硬質レジン (エナメル部)， 回：硬質レジン(デンチン部)，

: 可視光線重合型コンポジットレジン

図 1 実験に用いた試片の模式図

\section{III. 実験方法}

\section{1. 被着試片の製作}

試料は硬質レジン菌の摩耗を想定して Endura の咬合 面側のデンチン部硬質レジンが露出するまで平坦に削除 して, $20 \times 15 \times 10 \mathrm{~mm}$ の長方形のシリコン製モールドの 底に正置し，流し込みレジン（ポアーレジン,松風社製） にて包埋した（図 1-a）.

流し込みレジン重合完了後, 臨床において污染面を除 去し新生面を出すことを想定して, 試験研磨機 (L-1000, ウインゴー精機社製）にてシリコンカーバイドペーパー 120 番で研磨した。

\section{2. 人工歯の被着面処理}

被着面は $\mathrm{E}$ 鼡で処理した後，以下 4 種の条件の試片を 準備した.

1. $\mathrm{B}$ 剂を塗布したもの（以下， $\mathrm{E}+\mathrm{B}$ と略す）

2. RA を塗布処理し $B$ 剂を塗布したもの

(以下, $\mathrm{E}+\mathrm{RA}+\mathrm{B}$ と略す)

3. PL を塗布処理し $B$ 剤を塗布したもの

$$
\text { (以下, } \mathrm{E}+\mathrm{PL}+\mathrm{B} \text { と略す) }
$$

4. RA を塗布処理した後 PLで塗布処理し, 続いて B 剂を塗布したもの

$$
\text { (以下, } \mathrm{E}+\mathrm{RA}+\mathrm{PL}+\mathrm{B} \text { と略す) }
$$

な抢各々の処理剂の使用方法は主に指示書に従い行っ た. $\mathrm{E}$ 郕による処理効果においては論議はあるものの反 応阻害因子を除去する目的 ${ }^{8)}$ で塗布し，60 秒後十分水洗 （15秒）してゲルを完全に洗い流し，油分のないエアー で十分乾燥 (15 秒) した．ボンディングでは，B 荗を薄 く塗布し ( 2 液性のB㓮の筧汼は 15 秒とした), 再び油 分のないエアーを十分吹きつけて (15 秒間) 揮発成分を 


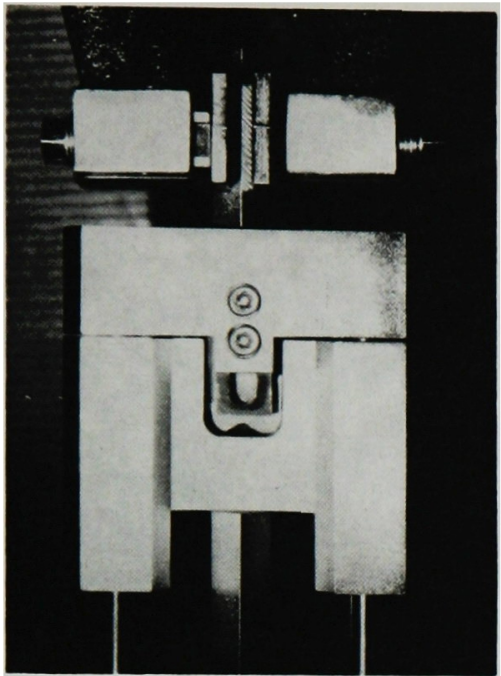

図 2 剪断試験装置

蒸発させ, 残ったレジン液をできるだけ薄い均一層に拡 げた. その後, 光重合器 (トランスルックス CL, Kulzer 社製）にて光を照射（10秒）してB剂を硬化させた.

表面処理剤については RA は筆で一層均一に塗布しエ アーシリンジで軽く乾燥させ，また PL は 2 液性である ため等量混和後塗布し, エアーシリンジで軽く乾燥させ た.

\section{3. レジン添加填入}

準備した各試片の人工歯被着面の上に内径 $3 \mathrm{~mm}$ (面 積 ; $7.165 \mathrm{~mm}^{2}$ ), 高さ $2 \mathrm{~mm}$ の透明アクリル環を正固し コンポジットレジンを填入する窩洞とした．窩洞に無圧 で LITE-FIL P を填入した後, 光重合器によりアクリ ル環の 4 方向から 10 秒ずつ照射し室温中で重合し，そ の後アクリル環を除去した（図 1-b).

レジン填入 10 分後に試片を 37 度蒸溜水中に浸漬し 24 時間保管した. なお試片は各群 10 個とした.

また, 参考として従来のアクリリックレジン歯（ウェ アレス, 而至社製) に, 即時重合レジン（ユニファス ト，而至社製）を筆積み法により填入した試片（以下, レ歯十即重と略す）を作製した。

\section{4. 剪断試験法}

接着强さの測定には各試片を装着した剪断 試 験 装 置 （図 2 ）を，万能試験機（オートグラフ S-2000, 島津製 作所社製）に取り付けクロスヘッドスピード $1 \mathrm{~mm} / \mathrm{min}$ にて行い, 剪断破折荷重を単位面積あたりの接着強さと した.

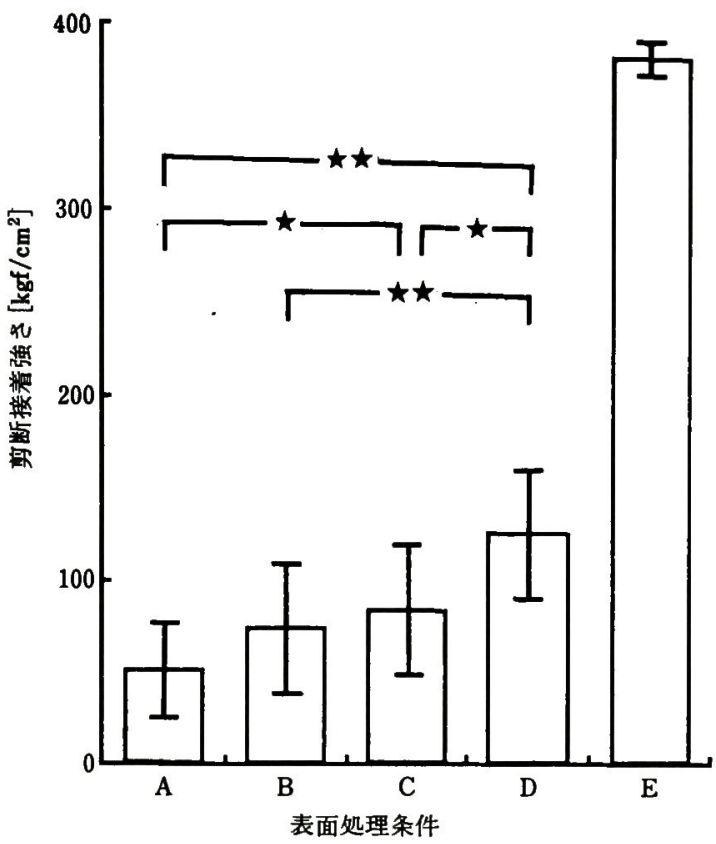

図 3 表面処理条件の違いによる剪断接着強さ $A: E+B, B: E+R A+B, C: E+P L+B$, $\mathrm{D}: \mathrm{E}+\mathrm{RA}+\mathrm{PL}+8, \mathrm{E}:$ レ歯+即重 $\star:$ p $0.05, \star \star: \mathrm{p}<0.01$ (t-test)

\section{IV. 実験結果}

各々の表面処理をした試片の接着強さと標準偏差を困 3 に示す．試片はすべて界面破壊であり， E+B の接着強 さは $52.6 \pm 58.8 \mathrm{kgf} / \mathrm{cm}^{2}, \mathrm{E}+\mathrm{RA}+\mathrm{B}, \mathrm{E}+\mathrm{PL}+\mathrm{B}$ は各々 $75.9 \pm 38.4 \mathrm{kgf} / \mathrm{cm}^{2}, 85.0 \pm 38.2 \mathrm{kgf} / \mathrm{cm}^{2}$ の值であった. $\mathrm{E}+\mathrm{PL}+\mathrm{B}$ の場合においては $\mathrm{t}$-検定の結果, 危険率 $5 \%$ で $\mathrm{E}+\mathrm{B}$ の場合と比べ有意差が認められた.また $\mathrm{E}+\mathrm{RA}$ $+\mathrm{PL}+\mathrm{B}$ の接着強さは $127.7 \pm 37.7 \mathrm{kgf} / \mathrm{cm}^{2}$ であり $\mathrm{t}$ 検定の結果，危険率 5\% で E+PL+B と，危険率 $1 \%$ で $\mathrm{E}+\mathrm{B}, \mathrm{E}+\mathrm{RA}+\mathrm{B}$ と比べ有意差が認められた。

また, レ歯十即重は $386.0 \pm 9.4 \mathrm{kgf} / \mathrm{cm}^{2}$ であった。

\section{V. 考察}

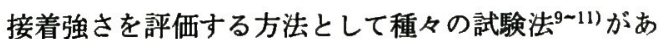
るが, 口腔内で人工歯の, 摩耗封に作用する力としては 咬合力の側方剪断成分が最も重要と考えられる。また一 般に材料の接着強度は垂直力に対する破壊強度よりも剪 断強度は低いために ${ }^{12)}$ 本実験では剪断試験法により評価 


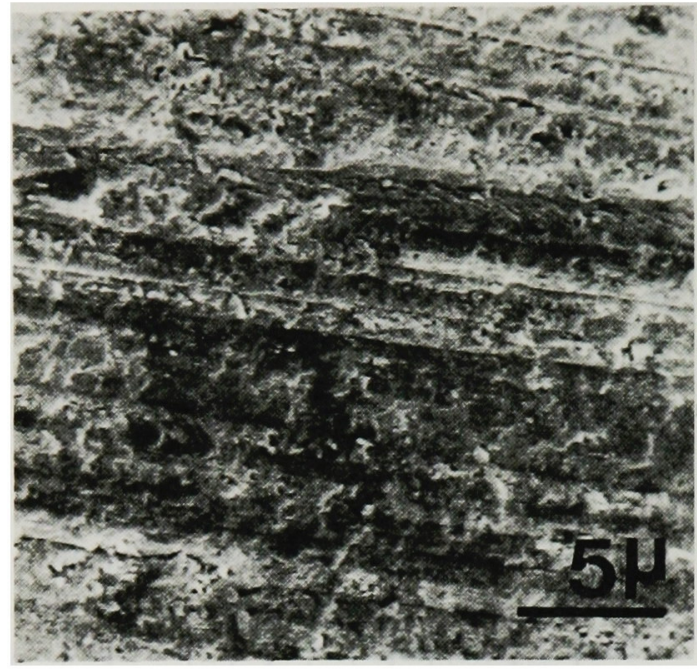

a

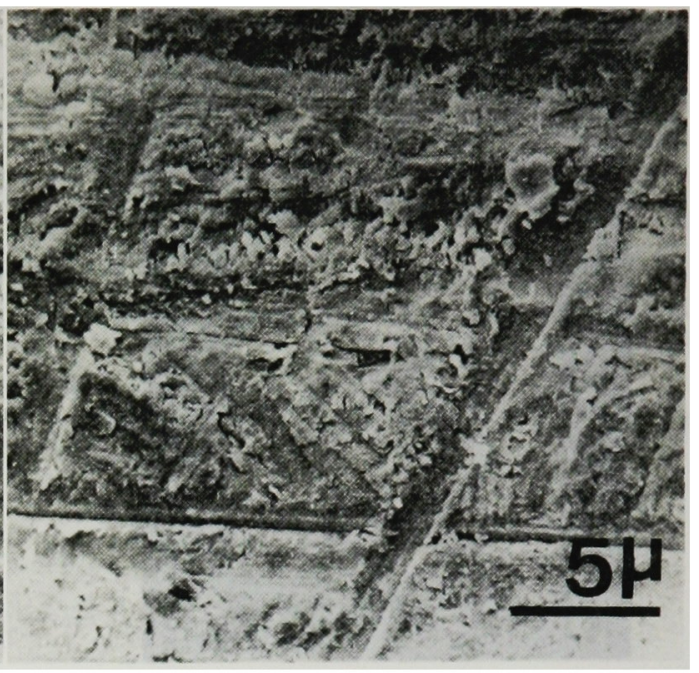

b

図 4 酸エッチング後無処理 (a) と有機溶剈 (RA) 処理 (b) OSEM 像, $\times 3,000$

することとした.

硬質レジンの被着面の処理は通常のコンポジットレジ ンの酸エッチング後, ボンディング処理したもの（E+ B）と，その操作の閒に塩素系有機溶剤により処理をし たもの $(\mathrm{E}+\mathrm{RA}+\mathrm{B})$ とシランカップリング剂により処 理をしたもの $(\mathrm{E}+\mathrm{PL}+\mathrm{B})$, またそれらの組合せ処理を したもの $(\mathrm{E}+\mathrm{RA}+\mathrm{PL}+\mathrm{B})$ の 4 種の条件において検討 した.

その結果, 硬質レジン歯へのコンポジットレジンの添 加調整の際には, 酸エッチング後有機溶剤による処理を 行い, 続いてシランカップリング剤による処理を行った 後ボンディング剂を塗布したもの $(\mathrm{E}+\mathrm{RA}+\mathrm{PL}+\mathrm{B})$ が， 最も強く結合することがわかった.

このことはその効果における論議はあるものの, 反応 阻害因子を除去する目的 ${ }^{8)}$ で酸エッチング処理を行い, 続いて塩素系有機溶剤 (RA) にてさらに化学的清掃を行 うと同時に, ポリマー鎖を拡大して硬質レジン歯の表面 に凹凸の形成を行う。この凹凸により，コンポジットレ ジンとの間に機械的結合力が働くものと考えられる. そ の効果の確認のため人工歯処理面のうち, 酸エッチング 後無処理のものと, RA 処理のものについて SEM 像に よる観察を行った．通法に従い金蒸着を施した後に走査 型電子顕微鏡（JSM-50 A, 日本電子社製）にて, 3,000 倍で写真撮影を行った. 図 4 に示すように酸エッチング 後無処理のものに比べ, RA 処理を行うと硬質レジンの 表面に凹凸が形成されることが観察された.

また次の処理として，シランカップリング剤 (PL)を
塗布した場合には化学的結合力が働くものと考えられ る. シランカップリング剤は元来, 有機相と無機相の両 方に反応し化学結合するケイ素原子を 1 つ有する化合 物8) である. 今回の使用に際しては, 硬質レジン人工歯 (Endura）の硬質レジン部のデンチン部は，超微粒子フ ィラー配合のウレタン系レジンである ${ }^{13)}$ が，その有機相 であるレジン部，無機相である超微粒子フィラー部と添 加したコンポジットレジンとの閒にシランカップリング 剤による化学的結合力が働いたもの ${ }^{14)}$ と思われる.

したがって酸エッチング処理後, 塩素系有機溶媒 (RA) による処理を行い続いてシランカップリング 剂 (PL) による処理後ボンディング剤を塗布した場合 (E+ $\mathrm{RA}+\mathrm{PL}+\mathrm{B})$ には, RA 処理による機械的結合力と $\mathrm{PL}$ 処理による化学的結合力により最も強い結合力が得られ たものと思われる.

本実験における接着強さは, 参考実験に示される従 来頻繁に行われているアクリリックレジン歯に即時重合 レジンを筆積み法にて行った際 (レ歯十即重) の值ほど 大きな接着強さは示さなかった. しかし，その值ほど人 工歯人添加されたものが強く接着する必要があるかは疑 問が残る. 剪断試験ではなく抗張破折試験ではあるが, 奥野ら ${ }^{15)}$ は土歯と床用レジンとの結合強さにおいて， 人工歯の剝離または破折時の総荷重量が $15.6 〜 18.1 \mathrm{~kg}$ 程度の強さであれば十分な接着力であると報告してい る. また硬質レジン歯と床用レジンとの接着強さにおい

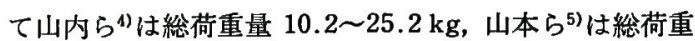
量 $9.7 \sim 14.7 \mathrm{kgf}$ (単位面積に換 算すると $29 \sim 47 \mathrm{kgf}$ / 
$\mathrm{cm}^{2}$ ) であると報告している.一般に材料の接着強度 は 垂直力に対する破壊強度よりも剪断強度は低いため12), 今回の結果の $100 \mathrm{kgf} / \mathrm{cm}^{2}$ を越える值は上記の引張り接 着強度と同等もしくはそれよりも高いことが推定される ので，臨床上使用に耐えられるのではないであろうか.

また本実験では ENDURA POSTERIO のデンチン部 を使用したが， ENDURA ANTERIO のエナメル部， ENDURA POSTERIO のエナメル部も使用目的の違いに より多少成分の調整はしてあるものの主成分には差がな いため16,17)，これらの部位にも応用できると考えられ る.

今後, 口腔内では長時間唾液にさらされ飲食物により くり返し温度変化を受けることにより接着面は吸水によ る材質劣化が考えられる.さらに咬合力等の外力がくり 返し複雑に加わるので度労現象も加わるため, 熱サイク ル試験 ${ }^{18)}$ また反復衝擊試験5) にて接着強さを検討寸る必 要があると思われる．またシランカップリング剤の種類 により接着力は異なる ${ }^{(9)}$ ため材料間による接着強さも検 討する必要があると思われる.

\section{VI. 結 論}

硬質レジン歯への可視光線重合型コンポジットレジン の添加修正の際においては，人工歯の新生面を出した 後, 酸エッチング処理, 塩素系有機溶㓮 REBASE AID による処理をし続いてシランカップリング剤 Porcelain Liner M による処理をした後ボンディング剤を塗布し たものが強く結合することがわかった。

稿を終えるにあたりにご教示頂いた京都大学生体医療工学セ ンター 都賀谷紀宏助手, 大阪大学齿学部中央研究所 佐藤良夫 技官に感刢の意を表します。

また资料などの提供に対し松風社, Sun-Medical 社, 德山曹 達社にも捄礼申し上げます。

\section{文献}

1）横山政高：日歯レジン歯の使用を考える臨床例の咬耗の観 察から, 補緅臨床, 19:163 171, 1986.

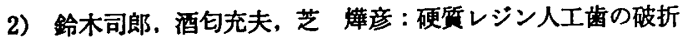
に関する研究, 補緅誌, $32: 780 \sim 786,1988$.
3）鈴木司郎、久根下斉、芝 燁彦ほか：硬倎レジン人工歯と 床用レジンの結合性について, 補緅誌， $32: 37 \sim 42,1988$.

4）山内六男，奥村清和，堺 誠ほか：硬啠レシシン歯と床用 レジンとの結合力について, 補緅誌, $32: 1275 \sim 1282$, 1988.

5）山本 滋, 竹内貫康, 清水洋一ほか：人工歯と床用レシシン の接着強さ一市販硬質レジン歯について一, 歯科技工, 18 : 197 203, 1980.

6) IM, S. and Williams, P.T. : Shear bond strength of composite resin repaired polymeric den ure teeth, J Dent Res, $68: 271,1989$.

7）細田裕康、山田敏元, 哄哲二郎ほか：コンポジットレジン の分類とフィラー組成に関する研究 (第 3 報) 日菌用可視 光線重合型レジンの分類, 日歯保誌, $30: 443 \sim 456,1987$.

8）高橋英登：シランカップリング剂の臨床応用，齿科ジャー ナル, $25: 26 \sim 36,1987$.

9) Fusayama, T., Nakamura, M., Kurosaki, N. et al : Non-pressure adhesion of a new adhesive restorative resin, J Dent Res, $58: 1364 \sim 1370,1979$.

10）千葉一雄, 奥谷謙一郎, 山田敏元ほか：臼㐘修復用コンポ ジットレジンの追加充塓に関する研究一充塓後比較的短期 の場合について一, 日㐘保誌, $28: 630 \sim 641,1985$.

11) Diaz-Arnold, A.M., Schneider, R.L. and Aquilino, S. A. : Bond strength of intraoral porcelain repair materials, J Prosthet Dent, 61 : 305 309, 1989.

12）接着研究会 編: 接着便覧, 高分子刊行会, 京都, 1966.

13）淟上隆男, 森 博史 : 新しい硬質レジン齿の理論的背景と 効果的使用，歯科技工，16:771 790，1988.

14）稲井紀通，大道博文，細田裕康：臼歯修復用コンポジット レジンの追加充填曲げ接着強さに関する研究 (第 1 報) 充 填後短時間の追加充塓及びシラン処理剤を使用した場合の 効果について, 日歯保誌, $31: 22 \sim 139,1988$.

15）奥野善彦, 野首孝祠, 佐野敬一：注入型レジンとレジン歯 との接着に関する研究, 補経誌, $17: 445 \sim 453,1973$.

16）（株）松風編：硬化レジン歯（エンテュラ）の技術资料, 1988.

17）松尾悦郎, 豊田 蔶: 新しいタイプの硬質レジン歯とパー シャルデンチャー, デンタルエコーVol. 80, 1988.

18）増原英一:「接着強さ」と「接着力」, DE. $62: 38 \sim 40$, 1982.

19) Williams, V.D. and Svare, C.W. : The effect of fiveyear storage perior to bonding on enamel/composite bond strength. J Dent Res. $64: 151 \sim 154.1985$. 